\title{
Microbial-Induced Carbonate Precipitation for Strengthening Soft Clay
}

\author{
J. Z. Xiao ${ }^{D},{ }^{1}$ Y. Q. Wei, ${ }^{1}$ H. Cai, ${ }^{1}$ Z. W. Wang, ${ }^{1}$ T. Yang, ${ }^{2}$ Q. H. Wang, ${ }^{2}$ and S. F. Wu ${ }^{1}{ }^{1}$ \\ ${ }^{1}$ State Key Laboratory of Simulation and Regulation of Water Cycle in River Basin, \\ China Institute of Water Resources and Hydropower Research, Beijing 100048, China \\ ${ }^{2}$ STECOL Corporation, Tianjin 300384, China
}

Correspondence should be addressed to J. Z. Xiao; xjz2006@sina.cn

Received 9 December 2019; Revised 11 March 2020; Accepted 23 March 2020; Published 14 April 2020

Academic Editor: Paweł Kłosowski

Copyright (c) 2020 J. Z. Xiao et al. This is an open access article distributed under the Creative Commons Attribution License, which permits unrestricted use, distribution, and reproduction in any medium, provided the original work is properly cited.

Currently, calcite produced in sediments by microbial-induced carbonate precipitation (MICP) is mainly used as a strengthening binder in sand because sands are porous and have good permeability. Conventional wisdom does not consider MICP to be suitable for use in soft clay because of the clay particles' small size and its minimal porosity. Because of the clay's high water content and complex chemical composition, very little research has been done and not much is known about the use of MICP in soft clay for strength enhancement. For this paper, soft clay specimens were prepared by mixing a solution containing Sporosarcina pasteurii bacteria, solutions with different concentrations of nutrient salts, and soft clay. Unconfined compressive strength tests were carried out on these specimens after they had cured for 28 days in a moisture-controlled environment. These laboratory tests were used to study the chemical reactions, the clay's strength, and other influencing factors. The results are as follows: (1) directly mixing a $S$. pasteurii solution, nutrient salts, and soft clay considerably improves the uniformity of the spatial distribution of the bacteria and the nutrients in the soft clay. Directly mixing these constituents promotes the formation of calcium carbonate and greatly simplifies soft clay sample preparation. (2) It is feasible to use MICP to increase the strength of soft clay. Compared to control specimens cured under the same conditions but without introduced nutrients and bacteria solution, the unconfined compressive strength of MICP-treated specimens can be increased by as much as 2.42 times to an unconfined compressive strength of $43.31 \mathrm{kPa}$. The water content in MICP-treated specimens was significantly reduced by the MICP reactions and in one case decreased from $40 \%$ to $30.73 \%$. (3) The strength enhancement of microbially solidified soft clay is the result of two processes: urea hydration catalyzed by enzymes consumes water in the clay and the bacterially precipitated calcite forms in the sediment's pores. (4) The micro-organism-produced calcite in the soft clay increases the calcite abundance from $0 \%$ to as much as $3.5 \%$. (5) The MICP-treated strength of soft clay varies with the concentration of the nutrients provided. For the experimental conditions used for this paper, the optimum concentration of the $\mathrm{CaCl}_{2} \cdot 2 \mathrm{H}_{2} \mathrm{O}$ and $\mathrm{CH}_{4} \mathrm{~N}_{2} \mathrm{O}$ nutrients is $0.5 \mathrm{~mol} / \mathrm{L}$.

\section{Introduction}

Most soft clay is deposited in still or very slowly flowing water. With the rapid development of the Chinese economy over the past few decades, more and more construction projects involving soft clay have been initiated such as construction for water conservation, land reclamation, and port and waterway hydraulic filling and dredging. These projects produce large amounts of soft clay. Owing to the clay's many unwanted engineering properties, geotechnical engineers almost always consider soft clay to be a problematic soil, and large tracts of arable land are needed to stack and store of the unwanted clay. The environmental pollution and arable land waste caused by soft clay disposal is becoming more and more serious, and these problems are attracting more and more public attention in China.

Soft clay, commonly composed of unconsolidated particles of illite and montmorillonite, has many undesirable engineering properties including high water content, high compressibility, low permeability, and low strength. It is easily deformed and commonly leads to stability problems [1]. To improve the clay's engineering properties and allow it 
to be used as a resource, different strengthening and solidifying methods are now employed such as mixing the clay with cement, lime, gypsum, or fly ash. These materials are used because they are easily available and inexpensive [2-7], but the effect of these admixtures on the clay's engineering properties is in some cases not ideal. The effects are constrained by the type and quantity of stabilizer material used, the moisture content of the soft clay, weathering condition, curing condition, and curing time, among other factors [8]. How much the clay is strengthened can be limited by these factors, and the use of some of these materials may be unacceptable for other reasons [9]. For example, air-drying the clay mixture may require a period of months and is strongly affected by the weather. In addition, air-drying can only reduce the water content on the clay's surface. After adding cement or lime as an additive, the drying time and shrinkage of soft clay increase considerably and the end product cracks easily [10]. The strength of lime-solidified soft clay increases slowly, and the time spent waiting delays construction and incurs additional costs. In addition, the production and use of these chemical additives produces different amounts of pollution [11]. For all these reasons, choosing a better method for strengthening soft clay is desirable and important for decreasing the nonproductive use of land.

Previous studies have shown that microorganisms reproduce rapidly [12-14]. The differentiation, accumulation, migration, and formation of mineral deposits of many elements on earth are closely related to microbial activity. Because of their rapid rate of reproduction, flexible metabolism, low energy consumption, variety, abundance, and ecofriendliness, the microorganisms used in microbial-induced carbonate precipitation (MICP) can have an important impact on the mechanical and engineering properties of soil $[12,15,16]$. At present, calcium carbonate produced by MICP is mainly used as a binder in sand [17-21]. Sand is a porous medium with good permeability $[22,23]$, that is, easy to grout, and the yield of calcium carbonate from microorganisms, the velocity of calcium carbonate precipitation, and the microorganisms' nutrient requirements in sand are relatively well known [20].

In contrast, the size of the particles in soft clay is mainly between $0.001 \mathrm{~mm}$ and $0.1 \mathrm{~mm}$, the porosity is minimal, and when the MICP method most commonly used in sandy soil, injecting a micro-organism-nutrient solution into the sand, is used on soft clay, the results have been mixed. Because of the clay's high water content and mechanical properties, only a few soil engineering studies have used MICP on soft clay. Morales et al. [24] evaluated the effects of biological treatment on silty clayey sand from southeastern Spain. Their experiments used only the nutrients available in the organic matter in the soil and in the compaction water for the added bacteria, and they found that the organogenic aggregates and bonds created during mixing and ageing may have been effective in improving the hydromechanical characteristics of the compacted soil. Keykha et al. [25] performed electrokinetic injection experiments using MICP-produced carbonate $\left(\mathrm{CO}_{3}{ }^{2-}\right)$ and calcium $\left(\mathrm{Ca}^{2+}\right)$ on soft clay (kaolinite) to increase the strength of the clay by precipitating calcite $\left(\mathrm{CaCO}_{3}\right)$.

The systematic study of MICP strengthening of soft clay is in the very early stages, and there are still many unanswered questions concerning how to use MICP more effectively in soft clay; the factors that influence the clay's strength enhancement need further study. This paper focuses on how MICP improves the strength of soft clay. Specimens were prepared by mixing a solution containing Sporosarcina pasteurii bacteria, nutrient salts, and soft clay together. Three different concentrations of nutrient solution were used and strength tests were carried out after the specimens had cured for 28 days. X-ray diffraction (XRD) was used to compare the mineralogy of the specimens, and the reaction mechanisms were systematically studied. The specimens' strength and the factors affecting that strength are discussed. This research will be valuable for using soft clay as a construction material after it has been strengthened by MICP.

\section{Soft Clay Specimens}

The soft clay was taken from clay exposed by the Qingyi River diversion excavation project in Wuhu City, Anhui Province, China. The location of Wuhu City is shown in Figure 1, and Figure 2 shows soft clay being excavated for sampling.

The water content of the clay on the site was $35 \%-62 \%$, the clay mineral content was $22 \%-40 \%$, and the saturated density was $1.89-1.93 \mathrm{~g} / \mathrm{cm}^{3}$. The clay was in a fluid or plastic state, the color ranged from gray to dark gray, and the clay was moderately to highly compressible.

The basic physical properties of the clay were tested following the procedures in the Chinese standard specification for soil tests, Specification SL237-1999. The results are listed in Table 1.

\section{Bacterial Solution}

The S. pasteurii used in the experiments was a chemoheterotrophic bacteria purchased from the Institute of Microbiology, Chinese Academy of Science. The cells were rod-shaped, $2-3 \mu \mathrm{m}$ in length, and $0.5-1.5 \mu \mathrm{m}$ in diameter, Gram-positive, and spore-round. The optimized medium was augmented with $20.0 \mathrm{~g}$ of yeast powder, $10.0 \mathrm{~g}$ of ammonium sulfate, and $1.0 \mathrm{ml}$ of nickel chloride in every $1.0 \mathrm{~L}$ of water. The $\mathrm{pH}$ of the medium was adjusted to 9.0, and then the medium was sterilized in a high-pressure steam sterilizing pot at $120^{\circ} \mathrm{C}$ for 20 minutes. After inoculation, the bacteria-bearing solution was cultured in a shaking incubator at $30^{\circ} \mathrm{C}$ shaken at $170 \mathrm{r} / \mathrm{min}$ for 24 hours.

According to the measurement taken, the initial optical density of the $S$. pasteurii solution at $600 \mathrm{~nm}\left(\mathrm{OD}_{600}\right)$ was 3.45 , and the urease activity was $1.22 \mathrm{~ms} / \mathrm{cm} / \mathrm{min}$ at $23.2^{\circ} \mathrm{C}$.

\section{Nutrient Salts}

The nutrients used in the experiments were $\mathrm{CaCl}_{2} \cdot 2 \mathrm{H}_{2} \mathrm{O}$ and $\mathrm{CH}_{4} \mathrm{~N}_{2} \mathrm{O}$. 


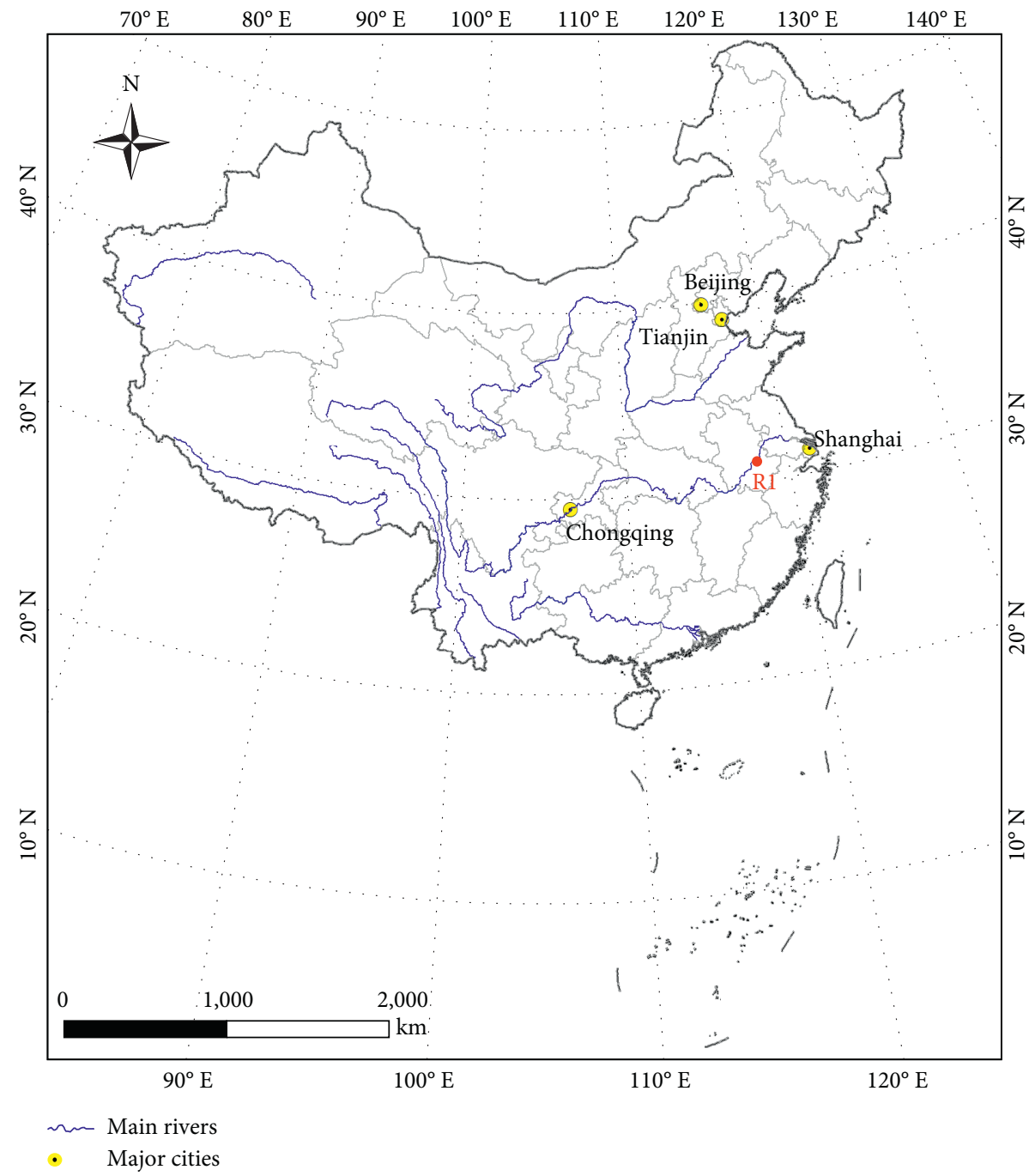

Figure 1: Location map showing Wuhu City, Anhui Province, China.

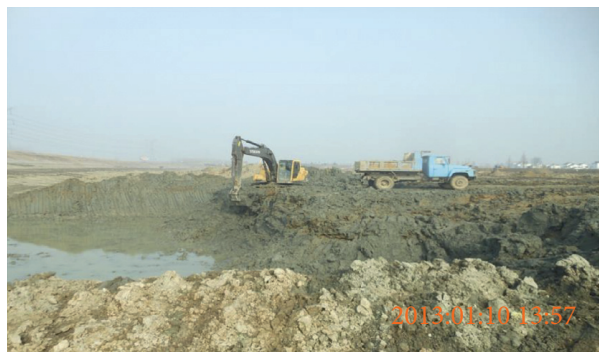

Figure 2: Soft clay being excavated adjacent to the Qingyi River for sampling.

TABle 1: Physical properties of the Qingyi River site clay used in this study. Soil tests were conducted in accordance with the Chinese standard SL237-1999.

\begin{tabular}{|c|c|c|c|c|c|c|c|c|}
\hline \multirow{2}{*}{ Material } & \multicolumn{3}{|c|}{ Grain composition (\%) } & \multirow{2}{*}{$W(\%)$} & \multirow{2}{*}{$\rho\left(\mathrm{g} / \mathrm{cm}^{3}\right)$} & \multirow{2}{*}{$G_{s}$} & \multirow{2}{*}{$W_{l}$} & \multirow{2}{*}{$W_{p}$} \\
\hline & $>0.075 \mathrm{~mm}$ & $0.075 \sim 0.005 \mathrm{~mm}$ & $<0.005 \mathrm{~mm}$ & & & & & \\
\hline Soft clay & 1.5 & 65.5 & 33 & 26 & 1.57 & 2.70 & 37.80 & 17.40 \\
\hline
\end{tabular}


To compare the effects of different nutrient concentrations on MICP strengthening, three different nutrient concentrations, $0.50,0.75$, and $1.00 \mathrm{~mol} / \mathrm{L}$, were used and two clay specimens with the same nutrient concentration were prepared for each specimen group.

For comparison, two control specimens and soft clay specimens that contained only the same weight water, with no nutrient salts and no bacteria solution added, were also prepared.

\section{Specimen Preparation and Curing}

Specimen preparation followed the procedures described in ASTM International standard ASTM D2166-00 [30] and Chinese technical standard SL237-1999 [31]. To compare the MICP strengthening effect of the different nutrient salt solutions better, the dry density and the initial water content of all the specimens was $1.35 \mathrm{~g} / \mathrm{cm}^{3}$ and $40 \%$, respectively.

Specimens were prepared as cylinders $3.91 \mathrm{~cm}$ in diameter and $8.00 \mathrm{~cm}$ long in a specimen mold. To ease demolding, a small amount of petroleum jelly ("Vaseline") was smeared on the inner surface of the specimen mold before the mold was filled. To prepare a specimen, the soft clay was mixed with the appropriate amount of solid nutrients in a container and then stirred until the nutrient salts and clay were well mixed, and the masses of nutrient salts added to the different specimen concentration groups are shown in Table 2. Then, the bacterial liquid was poured into the container containing the clay and nutrient salts, and the mixture was stirred evenly for 10 minutes. The mixed specimen material was then poured into the mold in five layers, and each layer was compacted, layer by layer, with a hammer. After the final layer was compacted, the two ends of the specimens were leveled.

According to the requirements of SL237-1999, the remolded specimens were carried out. The specimens were cured in a moisture cylinder (Figure 3 ) at $24^{\circ} \mathrm{C}$ and a relative humidity is $75 \%$ for 28 days. The moisture cylinder used for specimen curing in this study is the desiccator commonly used in the laboratory. It is a container with an arch top cover of broad frosted brim (Figure 3(a)), which can be fit well with the base. A perforated porcelain plate is placed in the middle of the base (Figure 3(b)). The bottom of the moisture cylinder under the porcelain plate is filled with water, and the soft clay samples are placed on the plate. In order to maintain the humid environment in the moisture cylinder during specimen curing, the top cover and the base are sealed with Vaseline.

After curing, unconfined compression tests were performed.

\section{Test Results}

6.1. Appearance Changes. Figure 4 is a photograph showing the soft clay specimens after had cured in the moisture cylinder for 28 days. It can be seen that the surfaces of the specimens inoculated with different concentrations of the nutrient salts differ considerably in appearance. There are numerous bacterial colonies on the surface of the $0.5 \mathrm{~mol} / \mathrm{L}$
TABLE 2: Mass of nutrient salts added to the soft clay specimen nutrient concentration groups and concentration group curing times (curing time $28 \mathrm{~d}$ ).

\begin{tabular}{lccc}
\hline $\begin{array}{l}\text { Nutrient } \\
\text { concentration } \\
(\text { mol/L) }\end{array}$ & $\mathrm{CaCl}_{2} \cdot 2 \mathrm{H}_{2} \mathrm{O}(\mathrm{g})$ & $\mathrm{CH}_{4} \mathrm{~N}_{2} \mathrm{O}(\mathrm{g})$ & $\begin{array}{c}\text { Dry density } \\
\left(\mathrm{g} / \mathrm{cm}^{3}\right)\end{array}$ \\
\hline 0.00 & 0.00 & 0.00 & 1.35 \\
0.50 & 3.79 & 1.55 & 1.35 \\
0.75 & 5.69 & 2.32 & 1.35 \\
1.00 & 7.58 & 3.10 & 1.35 \\
\hline
\end{tabular}

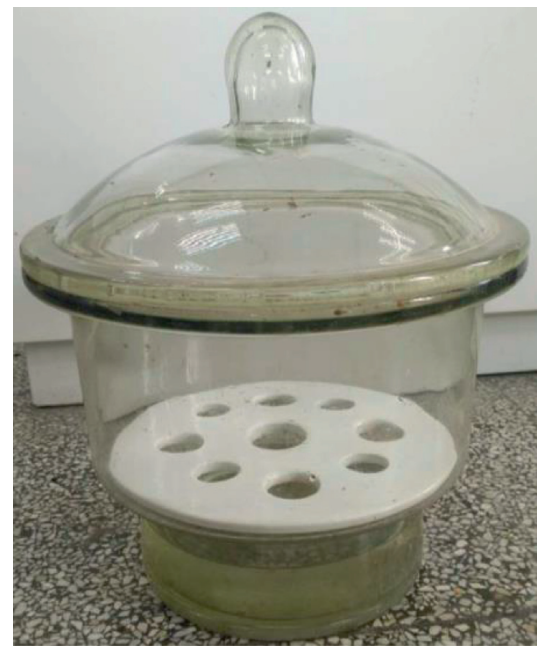

(a)

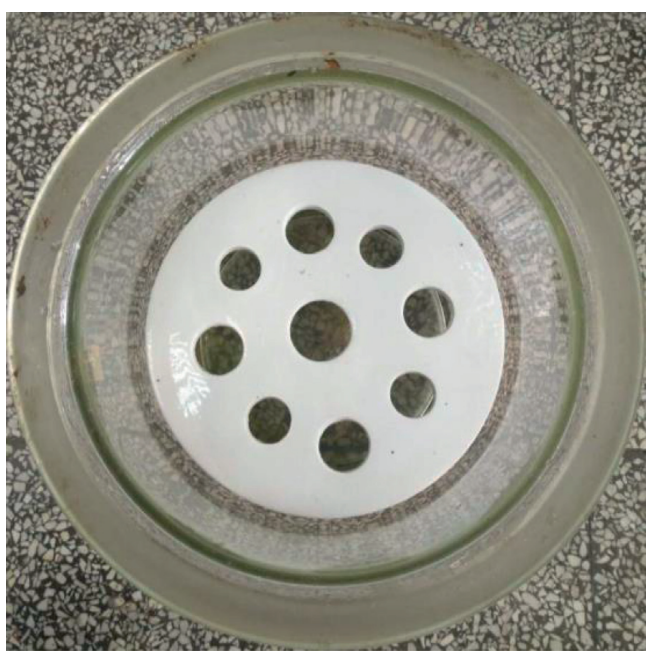

(b)

FIGURE 3: Moistening cylinder for curing sample.

nutrient specimen (Figure 5) but no bacteria growing on the specimens with only water added to the clay (Figure 6). The different appearances indicate that the different nutrient concentrations significantly influence the growth of $\mathrm{mi}$ croorganisms in soft clay cured at room temperature and $75 \%$ humidity.

During sample preparation, when the water is added to and mixed with the soft clay, any cemented aggregates in the clay will be broken and any remaining aggregates will be 


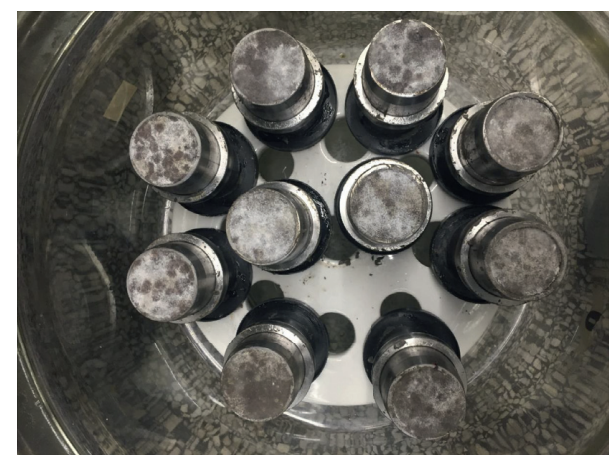

FIGURE 4: Soft clay specimens in the moisture cylinder after curing for 28 days.

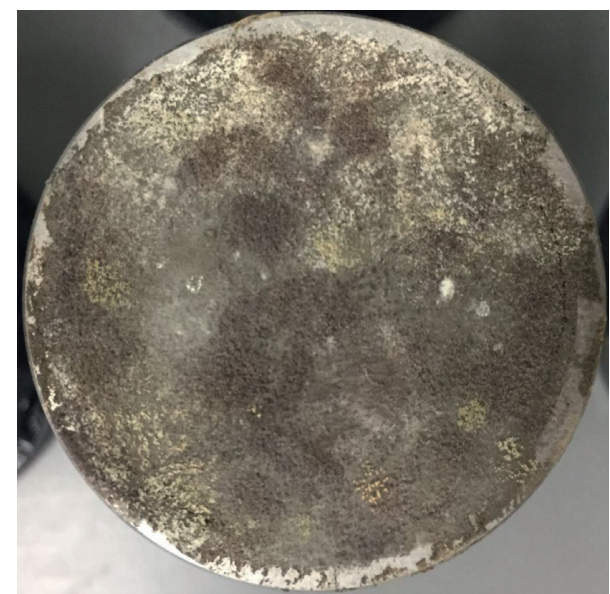

FIGURE 5: Photograph showing bacterial colonies on the surface of a $0.50 \mathrm{~mol} / \mathrm{L}$ specimen cured in the moisture cylinder for 28 days. Note that the clay specimen has not shrunk and the surface has not settled below the rim of the mold containing the specimen.

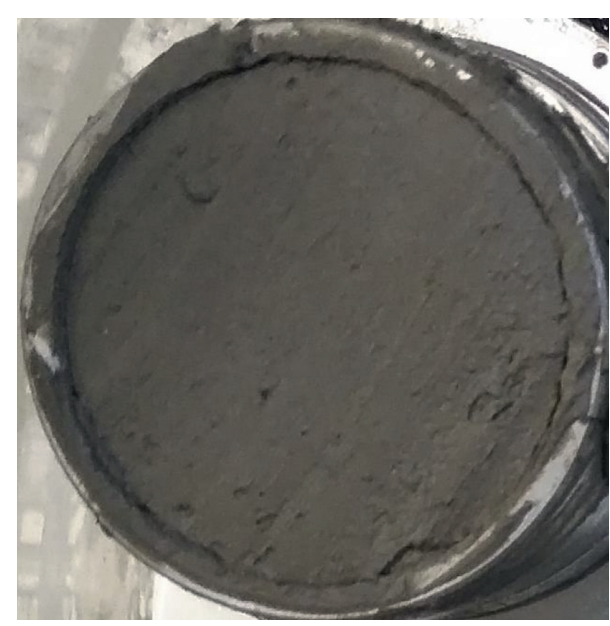

FIGURE 6: Photograph showing the surface of a $0.00 \mathrm{~mol} / \mathrm{L}$ specimen cured in the moisture cylinder for 28 days. Note that there are no bacterial colonies on the specimen's surface and the specimen has shrunk and settled below the rim of the mold containing the specimen. rearranged [26]. From Figure 5, it can be seen that the clay in a specimen treated with $0.5 \mathrm{~mol} / \mathrm{L}$ nutrients has not settled in the mold, but the no-nutrient specimen shown in Figure 6 has settled noticeably although both specimens, as described above, were cured under the same conditions.

6.2. Minerals and SEM Analysis. Minerals all have distinctive XRD patterns and the intensities of the characteristic peaks in the patterns correlate with the abundance of each mineral in the specimen. The mineral proportions can be approximated from the intensities of the diffraction peaks.

To compare the mineralogy and mineral abundances in the MICP-treated and cured soft clay specimens, XRD analyses were carried out according to SY/T 5163-2010 [32] (the Chinese standard for X-ray diffraction analysis of clay and ordinary nonclay minerals). The diffraction patterns were recorded using a Rigaku TTR III multifunction XRD instrument. Minerals abundances, normalized to $100 \%$, for four representative specimens are listed in Table 3, and XRD patterns for 0.00 and $0.50 \mathrm{~mol} / \mathrm{L}$ specimens are shown in Figure 7. The higher calcite peaks on the $0.50 \mathrm{~mol} / \mathrm{L} \mathrm{XRD}$ spectrum show that during the 28-day curing period, MICP in the nutrient-rich specimens precipitated calcite in the soft clay. After curing, the specimens with no nutrients and bacteria added contained no calcite, but in the nutrienttreated specimens, the specimens with $0.50,0.75$, and $1.00 \mathrm{~mol} / \mathrm{L}$ nutrient salts contained $2.7,2.8$, and $3.5 \%$ calcite, respectively.

The SEM/EDS images (Figure 8) are used to explore the presence and pattern of $\mathrm{CaCO}_{3}$ precipitation. As can be seen in Figure 8(a), the pores and fissures are observed in soft clay, and the calcium carbonate crystals induced by $\mathrm{mi}-$ croorganisms are distributed among the soft clay particles, with varying patterns at different positions, generally in the form of blocks or particles (Figure 8(b)), and the particle size of the microbial-induced calcium carbonate is close to that of the soft clay particles. The EDS analysis confirms that the mineral observed is calcium carbonate (Figure 8(c)).

6.3. Water Content Changes. When S. pasteurii metabolizes urea, it produces a urease that decomposes urea to form ammonium ions and carbonate ions. The reaction consumes water; the equation for the reaction is

$$
\mathrm{CO}\left(\mathrm{NH}_{2}\right)_{2}+3 \mathrm{H}_{2} \mathrm{O} \longrightarrow 2 \mathrm{NH}_{4}^{+}+\mathrm{HCO}_{3}+\mathrm{OH}^{-}
$$

Table 4 lists the changes in water content for the specimens. As shown in the table, at the end of the 28-d curing period, the water content in the two soft clay specimens to which no nutrients were added decreased from $40 \%$ to $39.84 \%$ and $39.89 \%$. These are decreases of $0.40 \%$ and $0.28 \%$ of the amount of water originally present, a negligible change. In contrast, the largest water content decrease in an MICP-treated specimen was from $40 \%$ to $30.58 \%$; this occurred in the specimen $0.50 \mathrm{~b}$ (a specimen with a nutrient concentration of $0.50 \mathrm{~mol} / \mathrm{L}$ ), and this is a $23.6 \%$ decrease in the specimen's water content. The smallest reduction in water content among the nutrient-enriched MICP 
TABLE 3: Ordinary nonclay mineral abundances in MICP-treated and cured soft clay specimens. Nonclay abundances were calculated from X-ray diffraction patterns.

\begin{tabular}{lcccccc}
\hline \multirow{2}{*}{ Nutrient concentration $(\mathrm{mol} / \mathrm{L})$} & \multicolumn{5}{c}{ Mineral content (\%) } \\
& Quartz & Potash feldspar & Plagioclase & Calcite & Hornblende & Clay mineral \\
\hline 0.00 & 49.3 & 3.4 & 9.3 & - & - & - \\
0.50 & 45.7 & 1.9 & 9.0 & 2.7 & 4.0 \\
0.75 & 43.4 & 1.1 & 7.2 & 2.8 & 1.9 \\
1.00 & 44.6 & 1.9 & 6.8 & 3.5 & - \\
\hline
\end{tabular}

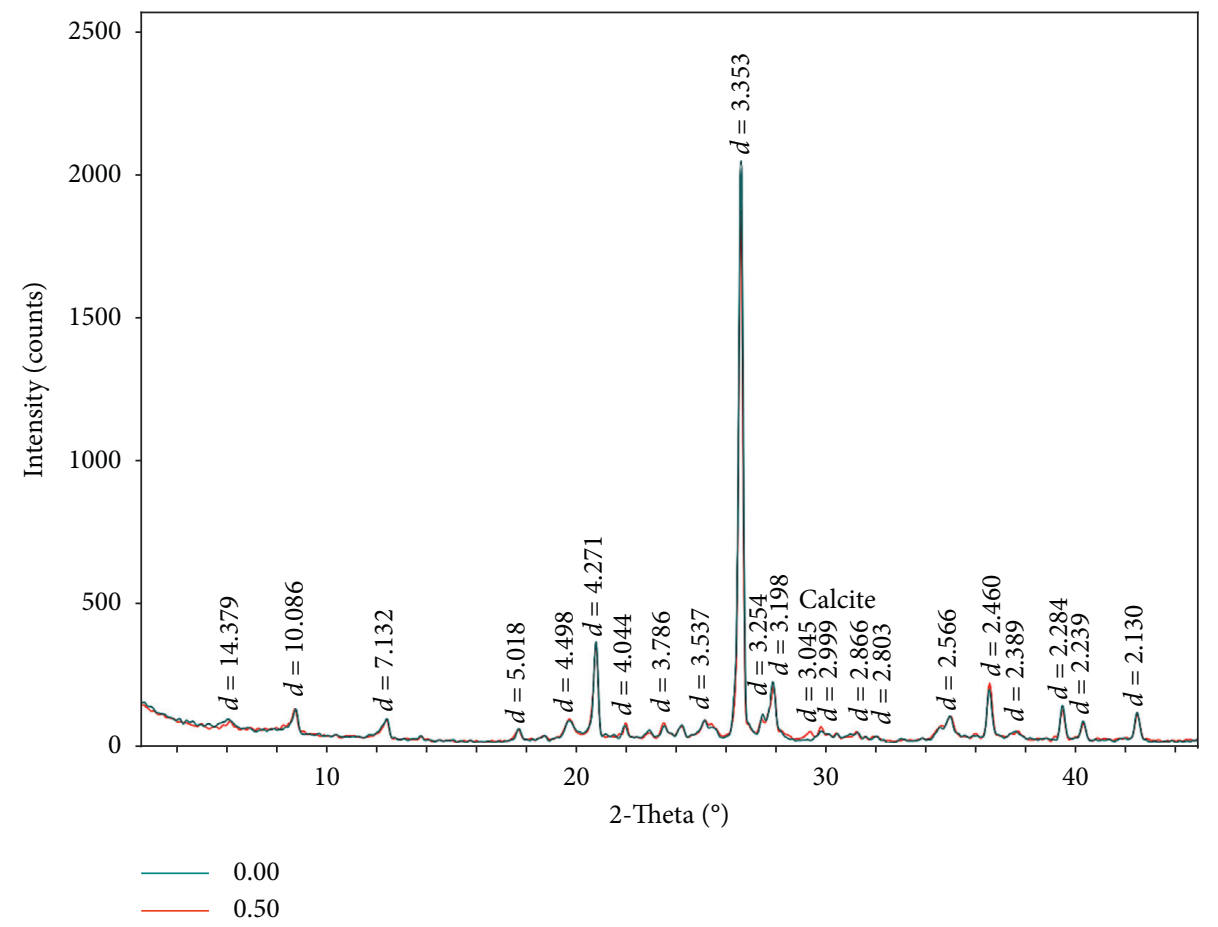

Figure 7: X-ray diffraction spectra for nonclay minerals in specimens infused with $0.00 \mathrm{~mol} / \mathrm{L}$ and $0.50 \mathrm{~mol} / \mathrm{L}$ nutrient salts.

specimens occurred in the $1.00 \mathrm{~mol} / \mathrm{L}$ group; the water content in the specimen 1.00 a dropped from $40 \%$ to $33.65 \%$, a decrease of $15.88 \%$. The average final water contents in the $0.00,0.50,0.75$, and $1.00 \mathrm{~mol} / \mathrm{L}$ nutrient concentration test groups were $39.86 \%, 30.73 \%, 32.20 \%$, and $32.51 \%$, respectively. Compared with the initial water contents of $40 \%$ in the specimens immediately after their preparation, the water contents in the four groups were reduced by $0.35 \%, 23.18 \%$, $19.50 \%$, and $18.73 \%$, respectively. The MICP treatment reduced the water content of the soft clay specimens significantly.

Reducing the water content increases the strength of soft clay considerably. The clay has a very low permeability, and the most commonly used method to reduce the clay's moisture content, air-drying, only removes water from the surface layer. This does not reduce the water content in the interior portions of a mass of soft clay and, in addition, airdrying has some obvious shortcomings. Air-drying takes a long time, is costly in terms of equipment and manpower downtime, and can be interrupted or stopped by bad weather. The effects of air-drying on the engineering properties of the soft clay are also not satisfactory. In contrast, the MICP treatment not only reduces the porosity but also reduces the water content of the entire mass of clay. This improves the clay's strength and thus is important if one wants to use the material for engineering purposes.

6.4. Unconfined Compressive Strength. Unconfined compression tests were performed on all the cured soft clay specimens in accordance with ASTM D2166-00. Tests were performed on a CMT 4304 Universal Testing Machine (MTS Systems Corp., Eden Prairie, MN, USA). The axial loading rate for the tests was $1.0 \mathrm{~mm} / \mathrm{min}$. The load decreased when the strain increased or until the strain reached $20 \%$.

In Figure 9, the differently colored curves are the stress-strain curves obtained from the unconfined compression tests on specimens with different nutrient concentrations; the "a" and " $b$ " labels identify the two soft clay specimens in each test group. The nutrient concentrations are indicated by the specimen numbers $(0.00,0.50,0.75$, and $1.00 \mathrm{~mol} / \mathrm{L}$ nutrient salts).

As shown in the figure, the stress-strain curves for the different nutrient concentrations have different shapes. Only the curves for specimens $1.00 \mathrm{a}, 1.00 \mathrm{~b}$, and $0.75 \mathrm{~b}$ reached peak values; for the other specimens, the axial stress 


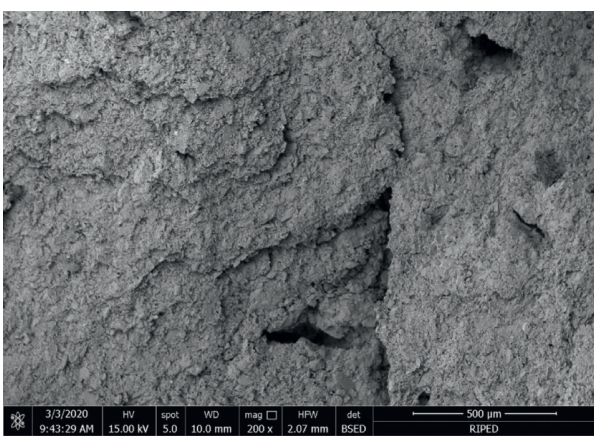

(a)

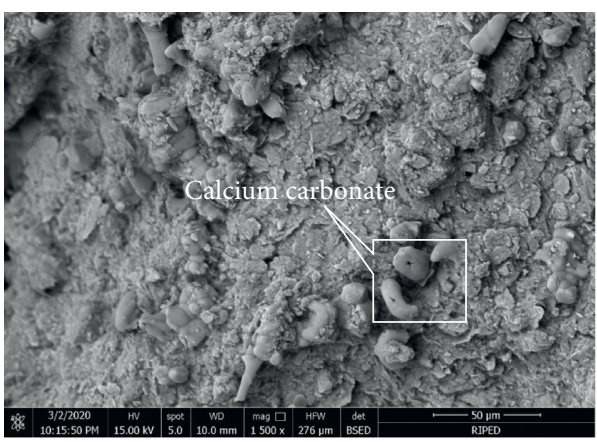

(b)
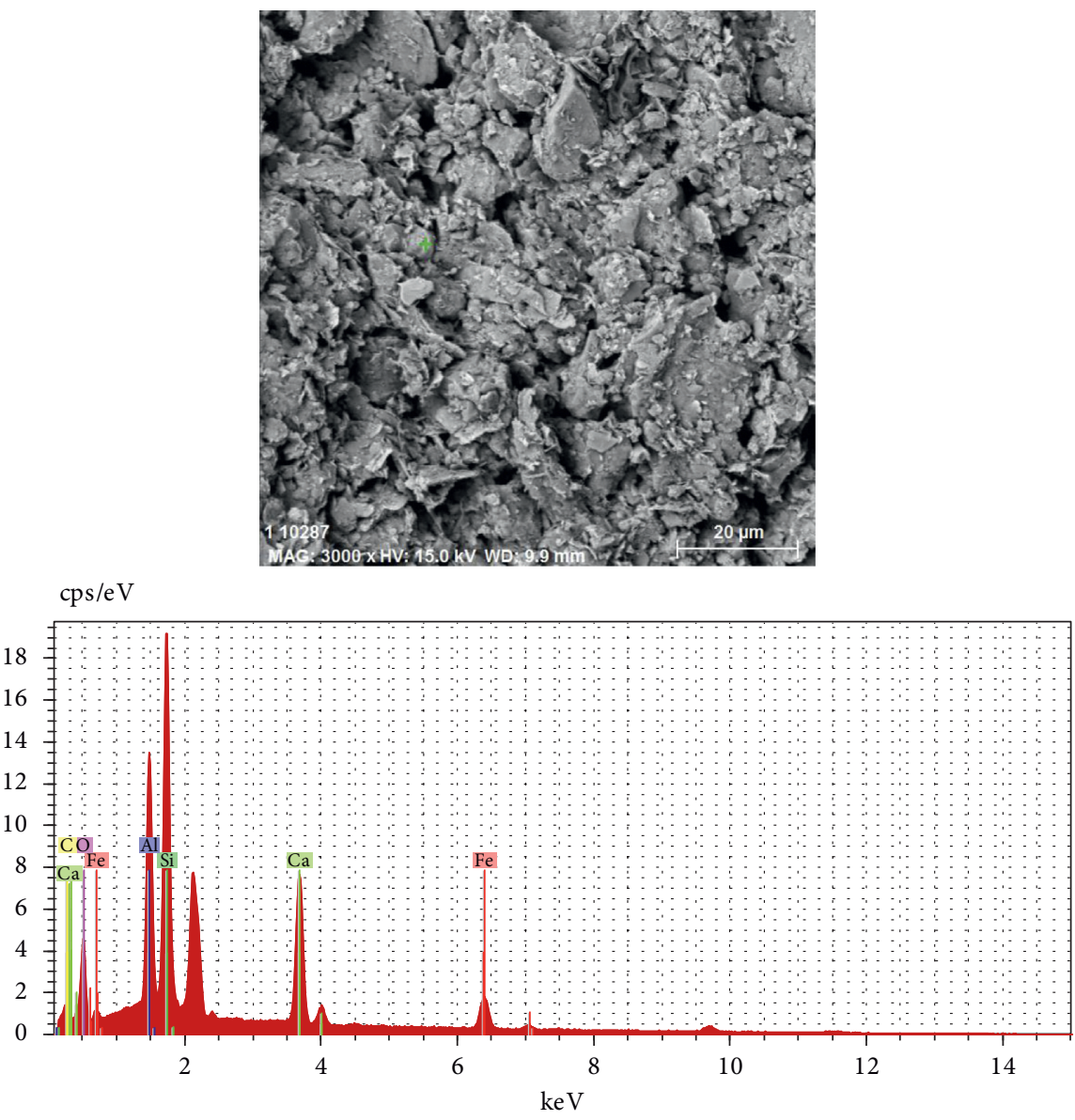

_ Acquisition_1 24584

(c)

FIGURE 8: SEM/EDS images of MICP-treated soft clay. (a) Voids and fissures in soft clay. (b) SEM image of calcium carbonate precipitation in soft clay. (c) The EDS test result.

increased steadily until the strain reached $20 \%$ (the tests were halted after the strain reached 20\%).

In the initial loading stages, the stress-strain curves rise approximately linearly with the increasing strain, but the rates at which the stress increases are different for the different test groups. The specimens that reach higher unconfined compressive strengths have higher stress growth rates, and thus, their stress-strain curves have steeper slopes before the highest stress is reached. After specimens $1.00 \mathrm{a}$, $1.00 \mathrm{~b}$, and $0.75 \mathrm{~b}$ reach their peak stress points, they reach their bearing capacity and as the strain continues to increase, the stress on these three specimens decreases slowly. Overall the general shape of the curves for these specimens is similar. The stress on the other specimens increased steadily with increasing strain, and the specimens exhibit a certain tendency towards plastic failure. For the specimen $0.00 \mathrm{~b}$, the stress decreases slowly after peak strain reaches its peak value, but the stress on the specimen $0.00 \mathrm{a}$ increases steadily as the strain increases and shows plastic deformation until the $20 \%$ experimental limit is reached. 
TABLE 4: Changes in soft clay specimen water content after curing for 28 days.

\begin{tabular}{lcccc}
\hline Specimen number & Nutrient concentration $(\mathrm{mol} / \mathrm{L})$ & Initial water content $(\%)$ & Treated water content (\%) & Average water content $(\%)$ \\
\hline $0.00 \mathrm{a}$ & 0.00 & 40 & 39.84 & 39.89 \\
$0.00 \mathrm{~b}$ & 0.00 & 40 & 30.88 & 39.86 \\
$0.50 \mathrm{a}$ & 0.50 & 40 & 30.58 & 30.73 \\
$0.50 \mathrm{~b}$ & 0.50 & 40 & 31.48 & 32.20 \\
$0.75 \mathrm{a}$ & 0.75 & 40 & 32.93 & 32.51 \\
$0.75 \mathrm{~b}$ & 0.75 & 40 & 33.65 & 31.36 \\
$1.00 \mathrm{a}$ & 1.00 & 40 & 40 & 36 \\
\hline
\end{tabular}

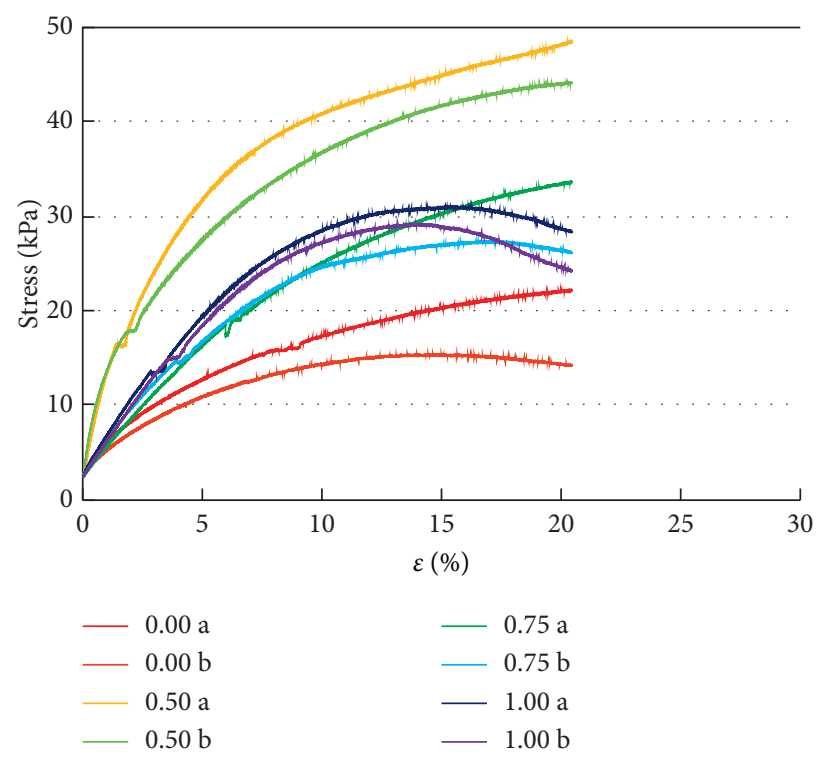

FIGURE 9: Stress-strain curves from the unconfined compression tests run on the soft clay specimens cured in the moisture cylinder for 28 days.

Obviously, the experiments show that the unconfined peak compressive strengths of MICP-treated soft clay specimens with different nutrient concentrations are different. As shown in Figure 9 and in Table 5, the highest maximum peak stress was recorded for specimen $0.50 \mathrm{a}$, $44.94 \mathrm{kPa}$, and the average peak stress for that test group of two specimens was $43.31 \mathrm{kPa}$. The lowest peak stress was $27.47 \mathrm{kPa}$ for the specimen $0.75 \mathrm{~b}$, and the average for the $0.75 \mathrm{~mol} / \mathrm{L}$ nutrient test group was $28.89 \mathrm{kPa}$. The average peak stresses for the $0.50,0.75$, and $1.00 \mathrm{~mol} / \mathrm{L}$ nutrient concentration test groups were $43.31,28.89$, and $30.19 \mathrm{kPa}$, respectively. These experimental results show that an optimal nutrient concentration exists for the MICP treatment of soft clay under the curing conditions used in these experiments. Under this nutrient concentration, the MICP reactions proceed more quickly towards completion and the clay's peak strength is higher.

The mechanism of soft clay solidification by MICP can be explained in two aspects. One is that urease is produced in the metabolism process of Bacillus Pasteurella, which decomposes urea to form ammonium ion and carbonate ion. Meanwhile, water in soft clay is consumed in this process (formula (1)). Therefore, the water content of soft clay is reduced, and the strength of MICP-treated clay is enhanced, which is similar to air-drying in the conventional solidification process of soft clay. On the other hand, the connection and filling of the microbial-induced calcium carbonate in the pores of soft clay also results in solidification:

$$
\mathrm{Ca}^{2+}+\mathrm{HCO}_{3}^{-}+\mathrm{OH}^{-} \longrightarrow \mathrm{CaCO}_{3} \downarrow
$$

The previous studies [27-29] have shown that high concentration of calcium ions in nutrient solution can significantly inhibit the urease activity. When the other conditions remain the same, the use of molar nutrient solution of calcium ion and urea with concentration more than $1.0 \mathrm{~mol} / \mathrm{L}$ will reduce the urease activity, which affects the solidification strength of the soft clay in the above two aspects. As a result, the solidification strength decreases at a concentration of $1.0 \mathrm{~mol} / \mathrm{L}$.

The maximum unconfined compressive strengths of specimens $0.00 \mathrm{a}$ and $0.00 \mathrm{~b}$, the control specimens with no nutrients and bacteria solution added, are the lowest; their maximum strengths were only $20.29 \mathrm{kPa}$ and $15.48 \mathrm{kPa}$ for an average of $17.89 \mathrm{kPa}$. The average strength is only about $41 \%, 62 \%$, and $59 \%$ of the average maximum peak strengths for the $0.50,0.75$, and $1.00 \mathrm{~mol} / \mathrm{L}$ nutrient specimens, respectively. In the unconfined compression test, when the 
TABLE 5: Unconfined compressive strength of soft clay specimens (curing time $28 \mathrm{~d}$ ).

\begin{tabular}{|c|c|c|c|c|c|}
\hline Specimen no. & $\begin{array}{l}\text { Nutrient concentration } \\
(\mathrm{mol} / \mathrm{L})\end{array}$ & Relative $\mathrm{CaCO}_{3}$ content (\%) & Average $\mathrm{CaCO}_{3}$ content (\%) & Stress $(\mathrm{kPa})$ & Average stress $(\mathrm{kPa})$ \\
\hline $0.00 \mathrm{a}$ & 0.00 & - & \multirow{2}{*}{-} & 20.29 & \multirow{2}{*}{17.89} \\
\hline $0.00 \mathrm{~b}$ & 0.00 & - & & 15.48 & \\
\hline $0.50 \mathrm{a}$ & 0.50 & 2.7 & \multirow{2}{*}{2.3} & 44.94 & \multirow{2}{*}{43.31} \\
\hline $0.50 \mathrm{~b}$ & 0.50 & 1.8 & & 41.67 & \\
\hline $0.75 \mathrm{a}$ & 0.75 & 2.8 & \multirow{2}{*}{2.5} & 30.30 & \multirow{2}{*}{28.89} \\
\hline $0.75 \mathrm{~b}$ & 0.75 & 2.2 & & 27.47 & \\
\hline $1.00 \mathrm{a}$ & 1.00 & 3.5 & \multirow{2}{*}{2.7} & 31.11 & \multirow{2}{*}{30.19} \\
\hline $1.00 \mathrm{~b}$ & 1.00 & 1.8 & & 29.26 & \\
\hline
\end{tabular}

axial strain of the specimen reaches $15 \%$, it is generally considered that the soil fails (ASTM D2166-00). For the specimen $0.00 \mathrm{~b}$, when the axial deformation is less than $15 \%$, it is basically the same type as the specimen 0.00 a, i.e., strain hardening.

Inspecting the data for mineral abundances listed in Table 3 and the data for unconfined compressive strength of the MICP-treated specimens in Table 5 shows that S. pasteurii causes calcite to precipitate in soft clay when a bacteria-bearing solution and nutrient salts are mixed directly with the soft clay. The amount of calcite in the specimens clearly increased during the 28-day curing period in the moisture cylinder. As shown in Table 3, the calcite content in an untreated specimen was $0.0 \%$, and the average unconfined compressive strength was $17.89 \mathrm{kPa}$. After MICP, the calcite contents in the other three specimens listed in Table 3 were $2.7 \%, 2.8 \%$, and $3.5 \%$, and the average unconfined compressive strengths for the $0.50,0.75$, and $1.00 \mathrm{~mol} / \mathrm{L}$ test groups were $43.31,28.89$, and $30.19 \mathrm{kPa}$, respectively.

It can be seen from Table 5 , the relative $\mathrm{CaCO}_{3}$ content for the $0.50 \mathrm{a}, 0.50 \mathrm{~b}, 0.75 \mathrm{a}, 0.75 \mathrm{~b}, 1.00 \mathrm{a}$, and $1.00 \mathrm{~b} \mathrm{~mol} / \mathrm{L}$ nutrient concentration test groups is $2.7 \%, 1.8 \%, 2.8 \%, 2.2 \%$, $3.5 \%$, and $1.8 \%$, respectively, and the average relative $\mathrm{CaCO}_{3}$ content for each group is $2.3 \%, 2.5 \%$, and $2.7 \%$, respectively, which is relatively low.

The relative content of calcium carbonate does not correspond to the unconfined compressive strength measured in the test. For example, the average relative content of calcium carbonate produced by microorganisms in the $0.5 \mathrm{~mol} / \mathrm{L}$ experiment group with the highest unconfined compressive strength of $43.31 \mathrm{kPa}$ is the lowest, only $2.3 \%$, which also shows that the water consumption in the process of microbial metabolism is an important factor for the improvement of soft clay solidification strength.

Comparing the water contents listed in Table 4 with the unconfined compressive strengths of the MICP-treated specimens listed in Table 5 shows that water content has an important influence on the strength of soft clay. The specimens in the $0.5 \mathrm{~mol} / \mathrm{L}$ test group (Figure 10), the test group with the highest average unconfined compressive strength, $43.31 \mathrm{kPa}$, have the lowest average post-MICP water content, $30.73 \%$. In addition, the average water contents for the specimens in the 0.75 and $1.00 \mathrm{~mol} / \mathrm{L}$ test groups were similar, $32.20 \%$ and $32.51 \%$, respectively, and the highest average unconfined compressive strengths were also was similar, 28.89 and $30.19 \mathrm{kPa}$, respectively. The

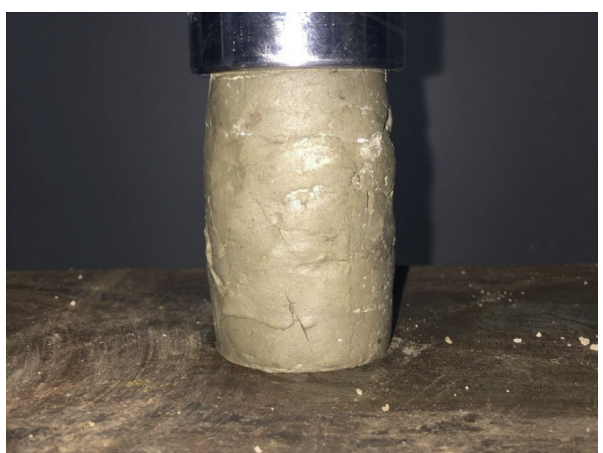

Figure 10: Photograph showing one of the $0.50 \mathrm{~mol} / \mathrm{L}$ soft clay specimens failing during an unconfined compression test.

untreated specimens had the lowest average water content reduction; the water content only fell from $40.00 \%$ to $39.86 \%$. These two specimens also had the lowest average unconfined compressive strength, only $17.89 \mathrm{kPa}$. This indicates that the water consumed by the MICP reactions in the soft clay is proportional to the increase in the clay's strength and that the water content reduction plays an very important role in improving the strength of soft clay.

In addition, it can be seen from Table 6 that the $\mathrm{CaCO}_{3}$ content for the $0.50 \mathrm{a}, 0.50 \mathrm{~b}, 0.75 \mathrm{a}, 0.75 \mathrm{~b}, 1.00 \mathrm{a}$, and $1.00 \mathrm{~b} \mathrm{~mol} / \mathrm{L}$ nutrient concentration test groups is $3.56 \mathrm{~g}$, $2.39 \mathrm{~g}, 3.73 \mathrm{~g}, 2.91 \mathrm{~g}, 4.62 \mathrm{~g}$, and $2.41 \mathrm{~g}$, respectively, and the average $\mathrm{CaCO}_{3}$ content for each group is $2.97 \mathrm{~g}, 3.32 \mathrm{~g}$, and $3.52 \mathrm{~g}$, respectively. Similar to Table 5 , it is maintained at a relatively low level. The calcium carbonate content does not correspond to the unconfined compressive strength measured in the test either. For example, the average content of calcium carbonate produced by microorganisms in the $0.5 \mathrm{~mol} / \mathrm{l}$ experimental group with the highest unconfined compressive strength of $43.31 \mathrm{kPa}$ is the lowest, only $2.97 \mathrm{~g}$, which also shows that the water consumption in the process of microbial metabolism is an important factor for the improvement of soft clay solidification strength.

\section{Discussion}

Soft clay has poor engineering properties including high water content, high compressibility, low permeability, and low strength. For a long time, the primary method for dealing with soft clay produced by construction projects has been to discard it as waste, and significant expanses of 
TABle 6: Detail of $\mathrm{CaCO}_{3}$ in height of soft clay specimens (curing time $28 \mathrm{~d}$ ).

\begin{tabular}{|c|c|c|c|c|c|}
\hline Specimen no. & Nutrient concentration $(\mathrm{mol} / \mathrm{L})$ & $\mathrm{CaCO}_{3}$ content $(\mathrm{g})$ & Average $\mathrm{CaCO}_{3}(\mathrm{~g})$ & Stress $(\mathrm{kPa})$ & Average stress (g) \\
\hline $0.00 \mathrm{a}$ & 0.00 & - & \multirow{2}{*}{-} & 20.29 & \multirow{2}{*}{17.89} \\
\hline $0.00 \mathrm{~b}$ & 0.00 & - & & 15.48 & \\
\hline $0.50 \mathrm{a}$ & 0.50 & 3.56 & \multirow{2}{*}{2.97} & 44.94 & \multirow{2}{*}{43.31} \\
\hline $0.50 \mathrm{~b}$ & 0.50 & 2.39 & & 41.67 & \\
\hline $0.75 \mathrm{a}$ & 0.75 & 3.73 & \multirow{2}{*}{3.32} & 30.30 & \multirow{2}{*}{28.89} \\
\hline $0.75 \mathrm{~b}$ & 0.75 & 2.91 & & 27.47 & \\
\hline $1.00 \mathrm{a}$ & 1.00 & 4.62 & \multirow{2}{*}{3.52} & 31.11 & \multirow{2}{*}{30.19} \\
\hline $1.00 \mathrm{~b}$ & 1.00 & 2.41 & & 29.26 & \\
\hline
\end{tabular}

formerly cultivated land have been converted to clay storage areas. This greatly increases the cost of projects that must remove large quantities of soft soil. Therefore, selecting an appropriate method for strengthening soft clay so it can be used as a construction material is important.

To find the appropriate strengthening method, this paper conducted MICP experiments using soft clay. A solution containing S. pasteurii bacteria was mixed directly with nutrient salts and soft clay, and a comparison of the reaction mechanism, strength, and influencing factors supports the feasibility of using MICP to strengthen soft clay. The experiments demonstrated that MICP can effectively increase the strength of the soft clay; the unconfined compressive strength can be increased by 2.42 times to $43.31 \mathrm{kPa}$, and the MICP reactions also reduce the clay's water content from $40 \%$ to $30.73 \%$.

Although this paper has analyzed the factors and mechanisms that strengthen soft clay by MICP, the experimental results are still preliminary because the special chemical composition and mechanical properties of the clay make the problem very complex. The following four aspects still need further investigation: (1) because the clay is not as porous as sandy material, the strength of soft clay can only be improved once by an MICP treatment. The strength of soft clay cannot be continuously improved by the repeated infusion of nutrient solutions, so additional study on soft clay microbial sampling methods is needed. (2) Additional research on the microbial treatment of high water content soft clay and on the mechanisms of strength improvement is required. (3) Further study on optimizing the combination of the bacteria and their nutrients in clays of different composition could lead to more efficient MICP. (4) As a corollary to point 3 , the differences in how microbial solidification affects different sedimentary types of soft clay should be investigated by comparative analysis.

\section{Conclusions}

(1) Directly mixing the Sporosarcina pasteurii solution, nutrient salts, and soft clay improves the uniformity of the spatial distribution of the bacteria solution and the nutrient salts in the clay. The improved distribution induces the formation of more calcite and has clear advantages for soft clay sample preparation.

(2) It is feasible to use MICP to improve the strength of soft clay. The unconfined compressive strength can be increased more than 2.42 times to an unconfined compressive strength of $43.31 \mathrm{kPa}$, and the MICP can also lower the clay's water content by $23 \%$ or more. Microbial-induced carbonate precipitation has a good prospect of being widely applied to turn soft clay into a useful construction material.

(3) The strength enhancement of microbially solidified soft clay is the result of two processes: urea hydration catalyzed by enzymes consumes water in the soft clay and the bacterially precipitated calcite formed in the sediment's pores.

(4) Calcium carbonate produced by microorganisms in soft clay is calcite, and the maximum calcite content of the clay can increase from $0 \%$ to as much as $3.5 \%$.

(5) The MICP-treated strength of soft clay varies with the concentration of the nutrients provided. For the experimental conditions used in this paper, the optimum concentration of the $\mathrm{CaCl}_{2} \cdot 2 \mathrm{H}_{2} \mathrm{O}$ and $\mathrm{CH}_{4} \mathrm{~N}_{2} \mathrm{O}$ nutrients is $0.5 \mathrm{~mol} / \mathrm{L}$.

\section{Data Availability}

The data used to support the findings of this study are included within the article.

\section{Conflicts of Interest}

The authors declare that they have no conflicts of interest.

\section{Acknowledgments}

This research was supported by the National Natural Science Foundation of China (grant no. 31670516) and Independent Research Topics of State Key Laboratory of Simulation and Regulation of Water Cycle in River Basin (grant no. SKL2018TS10). The authors thank David Frishman, PhD, from Liwen Bianji, Edanz Group China (http://www. liwenbianji.cn/ac), for editing the English text of a draft of this manuscript.

\section{References}

[1] G. L. S. Araújo, E. M. Palmeira, and Í. L. Macêdo, "Comparisons between predicted and observed behaviour of a geosynthetic reinforced abutment on soft soil," Engineering Geology, vol. 147-148, no. 12, pp. 101-113, 2012.

[2] A. Ahmed and U. H. Issa, "Stability of soft clay soil stabilized with recycled gypsum in a wet environment," Soils and Foundations, vol. 54, no. 3, pp. 405-416, 2014. 
[3] N. C. Consoli, D. Winter, A. S. Rilho, L. Festugato, and B. D. S. Teixeira, "A testing procedure for predicting strength in artificially cemented soft soils," Engineering Geology, vol. 195, no. 10, pp. 327-334, 2015.

[4] T. B. Edil, H. A. Acosta, and C. H. Benson, "Stabilizing soft fine-grained soils with fly ash," Journal of Materials in Civil Engineering, vol. 18, no. 2, pp. 283-294, 2006.

[5] D. F. Lin, K. L. Lin, M. J. Hung, and H. L. Luo, "Sludge ash/ hydrated lime on the geotechnical properties of soft soil," Journal of Hazardous Materials, vol. 145, pp. 58-64, 2007.

[6] M. A. Sakr, M. A. Shahin, and Y. M. Metwally, "Utilization of lime for stabilizing soft clay soil of high organic content," Geotechnical and Geological Engineering, vol. 27, pp. 105-113, 2009.

[7] A. Zukri, "Pekan soft clay treated with hydrated lime as a method of soil stabilizer," Procedia Engineering, vol. 53, pp. 37-41, 2013.

[8] A. Ahmed, "Compressive strength and microstructure of soft clay soil stabilized with recycled bassanite," Applied Clay Science, vol. 104, pp. 27-35, 2015.

[9] W. Yang, K. Wang, L. P. Li, S. C. Li, F. Xu, and S. Cheng, "Experimental analysis on the properties of different cementsoils with different cement content and curing times," in Proceedings of the Geo-China 2016, Shandong, China, July 2016.

[10] B. Fatahi, T. M. Le, B. Fatahi, and H. Khabbaz, "Shrinkage properties of soft clay treated with cement and geofibers," Geotechnical and Geological Engineering, vol. 31, pp. 14211435, 2013.

[11] L. Yadu and R. K. Tripathi, "Effects of granulated blast furnace slag in the engineering behaviour of stabilized soft soil," Procedia Engineering, vol. 51, pp. 125-131, 2013.

[12] J. T. DeJong, M. B. Fritzges, and K. Nüsslein, "Microbially induced cementation to control sand response to undrained shear," Journal of Geotechnical and Geoenvironmental Engineering, vol. 132, no. 11, pp. 1381-1392, 2006.

[13] W. D. Muynck, N. D. Belie, and W. Verstraete, "Microbial carbonate precipitation in construction materials: a review," Ecological Engineering, vol. 36, pp. 118-136, 2010.

[14] N. W. Soon, L. M. Lee, T. C. Khun, and H. S. Ling, "Improvements in engineering properties of soils through microbial-induced calcite precipitation," KSCE Journal of Civil Engineering, vol. 17, no. 4, pp. 718-728, 2013.

[15] H. Canakci, W. Sidik, and I. H. Kilic, "Effect of bacterial calcium carbonate precipitation on compressibility and shear strength of organic soil," Soils and Foundations, vol. 55, no. 5, pp. 1211-1221, 2015.

[16] J. T. DeJong, B. M. Mortensen, B. C. Martinez, and D. C. Nelson, "Bio-mediated soil improvement," Ecological Engineering, vol. 36, pp. 197-210, 2010.

[17] M. Azadi, M. Ghayoomi, N. Shamskia, and H. Kalantari, "Physical and mechanical properties of reconstructed biocemented sand," Soils and Foundations, vol. 57, no. 5, pp. 698-706, 2017.

[18] D. Bernardi, J. T. DeJong, B. M. Montoya, and B. C. Martinez, "Bio-bricks: biologically cemented sandstone bricks," Construction and Building Materials, vol. 55, pp. 462-469, 2014.

[19] B. C. Martinez, J. T. DeJong, and T. R. Ginn, "Bio-geochemical reactive transport modeling of microbial induced calcite precipitation to predict the treatment of sand in onedimensional flow," Computers and Geotechnics, vol. 58, no. 31, pp. 1-13, 2014.

[20] M. A. Shirakawa, K. K. Kaminishikawahara, V. M. John, H. Kahn, and M. M. Futai, "Sand bioconsolidation through the precipitation of calcium carbonate by two ureolytic bacteria," Materials Letters, vol. 65, no. 11, pp. 1730-1733, 2011.

[21] S. Stocks-Fischer, J. K. Galinat, and S. S. Bang, "“Microbiological precipitation of $\mathrm{CaCO}_{3}$," Soil Biology and Biochemistry, vol. 31, no. 11, pp. 1563-1571, 1999.

[22] D. J. Tobler, E. Maclachlan, and V. R. Phoenixa, "Microbially mediated plugging of porous media and the impact of differing injection strategies," Ecological Engineering, vol. 42, pp. 270-278, 2012.

[23] V. S. Whiffin, L. A. Van Paassen, and M. P. Harkes, "Microbial carbonate precipitation as a soil improvement technique," Geomicrobiology Journal, vol. 24, pp. 417-423, 2007.

[24] L. Morales, E. Romero, C. Jommi, E. Garzon, and A. Gimenez, "Feasibility of a soft biological improvement of natural soils used in compacted linear earth construction," Acta Geotechnica, vol. 10, pp. 157-171, 2015.

[25] H. A. Keykha, B. B. K. Huat, and A. Asadi, "Electrokinetic stabilization of soft soil using carbonate-producing bacteria," Geotechnical and Geological Engineering, vol. 32, pp. 739-747, 2014.

[26] J. Jia, X. L. Xie, and K. Yang, "Soil microstructure evolution and macro deformation mechanism for controlling construction disturbance in Shanghai soft soil," Journal of Shanghai Jiaotong University (Science), vol. 21, no. 6, pp. 713-718, 2016.

[27] S. M. Al-Thawadi, High strength in-situ biocementation of soil by calcite precipitating locally isolated ureolytic bacteria, Ph.D. thesis, Murdoch University, Perth, Australia, 2008.

[28] V. S. Whiffin, Microbial $\mathrm{CaCO}_{3}$ precipitation for the production of biocement, Ph.D. thesis, Murdoch University, Perth, Western Australia, Australia, 2004.

[29] Z. Yang and X. H. Cheng, "A performance study of highstrength microbial mortar produced by low pressure grouting for the reinforcement of deteriorated masonry structures," Construction and Building Materials, vol. 41, pp. 505-515, 2013.

[30] ASTM, Test Specification for Unconfined Compressive Strength of Cohesive Soil: ASTM D2166-00, ASTM International, West Conshohocken, PA, USA, 2004.

[31] SL237-1999, Specification of Soil Test, China Water \& Power Press, Beijing, China, 1999, in Chinese.

[32] SY/T 5163-2010, Analysis Method for Clay Minerals and Ordinary Non-clay Minerals in Sedimentary Rocks by the $X$-Ray Diffraction, Petroleum Industry Press, Beijing, China, 2010, in Chinese. 